\author{
Abstracta Iranica \\ Abstracta Iranica Revue bibliographique pour le domaine irano-aryen \\ Volume 34-35-36 | 2017 \\ Comptes rendus des publications de 2011-2013
}

\title{
Mehmet Karaosmanoḡlu, Hakim Korucu. "The Apadana of Altıntepe in the Light of the Second Season Excavation"
}

\section{Astrid Nunn}

\section{(2) OpenEdition Journals}

Édition électronique

URL : http://journals.openedition.org/abstractairanica/42806

DOI : 10.4000/abstractairanica.42806

ISSN : 1961-960X

Éditeur :

CNRS (UMR 7528 Mondes iraniens et indiens), Éditions de l'IFRI

\section{Référence électronique}

Astrid Nunn, "Mehmet Karaosmanoḡlu, Hakim Korucu. "The Apadana of Altıntepe in the Light of the Second Season Excavation" ", Abstracta Iranica [En ligne], Volume 34-35-36 | 2017, document 127, mis en ligne le 30 juillet 2017, consulté le 02 octobre 2020. URL : http://journals.openedition.org/ abstractairanica/42806 ; DOI : https://doi.org/10.4000/abstractairanica.42806

Ce document a été généré automatiquement le 2 octobre 2020.

Tous droits réservés 


\title{
Mehmet Karaosmanoḡlu, Hakim Korucu. "The Apadana of Altıntepe in the Light of the Second Season Excavation"
}

\author{
Astrid Nunn
}

\section{RÉFÉRENCE}

Mehmet Karaosmanoḡlu, Hakim Korucu. "The Apadana of Altıntepe in the Light of the Second Season Excavation", in A. Cilingiroğlu \& A. Sagona (eds.), Anatolia Iron Ages 7. The Proceedings of the Seventh Anatolia Iron Ages Colloquium Held at Edirne, 19-24 April 2010. ANES Suppl. 79, 2012, p. 131-147.

1 L'origine du type de la salle à colonnes (apadana) est controversée. Il en résulte de temps à autre des débats chronologiques sur une datation préachéménide ou non. L'apadana de Altıntepe est urartéenne et a subi un profond remaniement éventuellement après une destruction par séisme ou feu. Lors d'une seconde phase, la grande salle d'origine (vide) fut élevée, agrandie à $44 \times 25,30 \mathrm{~m}$ et munie de 18 colonnes. L'agrandissement engendra des changements du plan général, entre autre la disparition d'une cuisine attenante à la salle d'origine. 


\section{AUTEURS}

\section{ASTRID NUNN}

Université de Munich 